\title{
A TAXONOMIC REVISION OF MAZUS LOUR. (SCROPHULARIACEAE) IN AUSTRALASIA
}

\author{
by W.R. Barker
}

(with two text-figures)

\begin{abstract}
Mazus is shown to consist of three species in the Australia New Zealand region. Mazus pumilio R. Br. of past concepts is shown to consist of two species, $M$. pumilio s.str. being confined to southeastern Australia and a new species, M. novaezeelandiae, to lowland New Zealand; morphological floral differences may reflect different breeding systems, with the former thought to be self incompatible and the latter self-compatible. Mazus radicans (Hook. f.) Cheeseman is confined to New Zealand and extends to higher altitudes than M. novaezeelandiae. Its flowers may be small and cleistogamous or "bud-autogamous" as well as large and chasmogarnous. Distinctions from M. pumilus (Burm. f.) Steenis, a weedy southeast Asian annual extending to a few locations in New Guinea, are given in the key to species.
\end{abstract}

Key Words: Mazus, systematics, Australia, New Zealand.

In BANKS, M.R. et al. (Eds), 1991 (31:iii): ASPECTS OF TASMANIAN BOTANY - A TRIBUTE TO WINIFRED CURTIS. Roy. Soc. Tasm. Hobart: 85-94. https://doi.org/10.26749/rstpp.124.2.85

\section{INTRODUCTION}

Mazus is a genus of perennial or annual herbs primarily centred in southeastAsia, from China, Japan and Taiwan to the Himalayas. A single weedy species, M. pumilus (Burm. f.) Steenis, extends from there through the Indonesian archipelago to New Guinea and Fiji (Steenis 1958, Royen 1983, Barker 1982a). A widely disjunct minor centre of the genus occurs in Australia and New Zealand in which two specieshave long been recognised, M. pumilio $\mathrm{R}$. Br. in marshy sites in southeastern Australia and lowland New Zealand, and M. radicans (Hook. f.) Cheeseman confined to higher regions in New Zealand. In the present study, which is part of continuing investigations in the systematics of Australasian Scrophulariaceae, the genus is shown to comprise three species in the region.

\section{MATERIALS}

Specimens have been examined from the herbaria AD, AK, BRI, CANB, CBG, CHR, HO, MEL, NSW, OTA, WELT and WELTU in Australasia, and BM, CGE, G, K, E, FI, L, LY, M, P, SING, W and WU in the Northem Hemisphere. M. pumilio of Australia and its New Zealand segregate werecultivated by transplantation of stoloniferous material in the research glasshouse at the Adelaide Botanic Gardens.

\section{TAXONOMY}

\section{Mazus Loureiro}

Mazus Loureiro, Fl. Cochinch. (Sept. 1790) 385

Type species: $M$. rugosus Loureiro(=M. pumilus (Burm. f. ) Steenis, non $M$. pumilio $\mathrm{R}$. Br.).

\section{Description}

Stoloniferous or rhizomatous, perennial or annual herbs. Leaves opposite or (in some Asian species) the upper ones alternate, sometimes forming basal rosettes by shortening of the internodes, minutely gland-dotted ("punctate") at least on the lower surface (confirmed so far in Australian and New Zealand plants); midrib prominent on lower side. Inflorescences terminal or (outside Australia and New Zealand) axillary racemes with one to several alternate flowers, sometimes tending to paniculate by the production of a lateral raceme, sometimes scaptiform; bracts and bracteoles small, subulate, sometimes absent, the bracteoles alternate, borne on the pedicel well below the calyx. Calyx of 5 sepals fused in lower half or more into a tube, finely 5- or 10-ribbed. Corolla bilabiate; tube slightly longer than the calyx; upper lip porrect, 2-lobed; lower lip much larger, spreading, 3-lobed, with the throat behind comprising a raised palate of two longitudinal ridges covered (in the species seen) by clavate hairs. Stamens 4 , didynamous, joined in pairs at the anthers; anther locules 2 , confluent, widely divergent, separated by a distinct but incomplete septum. Ovary with many ovules; stigmas 2 broad flaps. Fruit a loculicidal capsule, the 
2 valves entire ( $\mathrm{Li}$ 1978) or ?indehiscent (see below); seeds many.

\section{Discussion}

This is a genus of mainly eastern and southern Asia, with almost all species from that region present in China (Li 1954). It was once considered to comprise about 30 species (Bonati 1908) but Li (1954), in a preliminary review of the genus, noted that these species had "fluid characters and [were] in general not clearly distinguishable from each other"; he later estimated there to be only about ten species in the genus ( $\mathrm{Li}$ 1978). On the other hand, Royen (1983) has estimated that it consisted of 50 species. Obviously the genus is in need of revision. Because of the apparent plasticity of characters, studies of cultivated plants may prove advantageous.

The traditional distinction between groups of species with either "stolons" or "rhizomes" (Bonati 1908, Li 1954) needs anatomical clarification.

In the absence of current revisional work in the genus, it has been considered desirable to formalise the results of the present study of the Australian and New Zealand representatives. There is no doubt that $M$, pumilio $\mathrm{R}$. Br. of prior concepts, which occurred in both countries, consists of two species confined to opposite sides of the Tasman Sea. Propagation of stoloniferous material to concurrent flowering in the same glasshouse showed the character differences discerned from the study of herbarium material to be maintained. In addition, the two species may differ in breeding system. In cultivation the plants of Mazus novaezeelandiae, provided by Mr T. Moss and Dr B.V. Sneddon (WELTU) from Queen Elizabeth Park, Paekakariki, formed fruits but $M$. pumilio s.str. (from Chinnock 6505) did not, indicating that the latter is an obligate outcrosser. The flowers were not bagged to prevent chance pollination by insects, nor could it be established whether the original material was from more than one plant, but it is likely that $M$. novaezeelandiae is self-compatible.

None of the capsules seen in the three species showed evidence of dehiscence. $\mathrm{Li}$ (1978) refers to capsules of Mazus being loculicidal with the valves remaining whole. It seems likely that the three Australasian species remain undehisced for some time; in the specimens of $M$. radicans in the collections Simpson CHR 205059 and Latter CHR 146045, for example, capsules are retained almost to the next flowering season.

Whether dehiscence takes place eventually and under what conditions remains to be investigated. Variation from the normal ready dehiscence of Scrophulariaceae is to be seen in other Australasian members of the subtribe Mimulinae. For example, in certain species of Peplidium and Glossostigma (Barker 1982a), capsules can be indehiscent while attached to a living plant. The walls become very fragile when they dry out after death of the plant; seed is dispersed when they shatter. Whether the greatly enlarged and reddened characteristics of the calyces of $M$. radicans are of some significance in dispersal also warrants study.

The derivation of Mazus, from the Greek mazos, meaning papilla or breast, is misconstrued by Hooker $(1853,1857)$ and subsequent authors (e.g. Black 1926, Robertson 1957). These authors considered it to allude to the two longitudinal ridges on the lower side of the corolla throat. Loureiro (1790) clearly derived his name from the clavate hairs (his pedunculate papillae) which block the throat.

In the lists in the text, the last collected specimen seen from a region is cited to allow assessment of endangerment of the species. Australian records are listed in the regions adopted by the representative state herbaria, while those from New Zealand are put in the regions used for the Flora of New Zealand (Allan 1961). A full list of specimens examined is available from the author. Distinctions from M. pumilus (Burm. f.) Steenis are given in the key opposite.

\section{Mazus pumilio R. Br.}

M. pumilio R. Br., Prod. (1810) 439 (incl. both unranked infraspecific taxa " $\alpha$ " and " $\beta$ "); R. Br., Manuscript (unpublished: Burbridge 1955) (incl. both unranked infraspecific taxa " $\alpha$ " and " $\beta$ "); et auctt. e.g., Endl., Ic. Gen. Pl. (1838) t.102; Hook., Ic. Pl. 6 (n.s. vol.2) (1843) t.567, excl. NZ occurrences); Benth. in DC., Prod.10 (1846) 375; Hook. f., Fl. Nov.-Zel. (1853) 189, p.p. (as to Australian records); Hook. f., Fl. Tasm. 1 (1857) 290 (excl. NZ reference); Benth., Fl. Aust. 4 (1868) 484, p.p. (excl. NZ reference); Cheeseman, Man. NZ Fl. 485, p.p. (excl. NZ reference); Bonati, Bull. Herb. Boiss. Ser.2, 8 (1908) 527, 528 (in conspectus and key); Allan, Fl. NZ 1 (1961) 848, p.p. (as to Australia and Tasmania references); Rotherham, Blaxell, Briggs \& Carolin, Fl. Pl. NSW \& S. Qld (1975) 168, t.556; W.R. Barker, Evol. Fl. Fauna Arid Aust. (1982) 342, p.p. (excl. NZ occurrence); W.R. Barker, Fl. S. Aust. (1986) 1284, fig.584.

Type citation: "(D [Insula Van Diemen]). v.v.". Lectotypus hic designatus: R. Brown Iter Australiense $2647,10.1 .1804$, In humidiusculis prope ripas fluvii Cataract river in Port Dalrymple; Mimuloides scapigera, [On reverse] Mazus pumilio $\alpha$, BM p.p. Isolectotypi syntypique: [R. Brown s.n.], 10.i.1804, Port Dalrymple, Mazus pumilio, BM. - R. Brown s.n., 1802-5, Port Dalrymple, E. - - R. Brown 2647, 1802 5, P[ort] Dalrymple, P p.p. Syntypi alteri: R. Brown Iter Australiense 2648, [24.iv.1802], Kings Island; Mazus pumilio $\beta$; Mimuloides minima, BM p.p., K p.p. 


\section{KEY TO THE SPECIES OF MAZUS IN AUSTRALASIA}

1. Annual, not forming horizontal runners or clones; branches erect to ascending, not rooting at nodes [Corolla purple (Steenis $22613 \mathrm{~L}$ )]..... M. pumilus

1. Perennial, forming horizontal runners either rooting at nodes or forming clonal off-shoots ..............2

2. Horizontal runners leafy, rooting at nodes ("stolons"). Leaves distant, with readily distinguishable internodes, with eglandular hairs, if present, moderately long to long. Calyx stout, broadly campanulate, always covered by sparse or dense eglandular hairs $(0.3) 0.5-0.8 \mathrm{~mm}$ long; teeth $2.5-4 \mathrm{~mm}$ long. Capsule truncate; seeds (0.8) $1.0-1.2 \mathrm{~mm}$ long. [Corolla $9-16 \mathrm{~mm}$ long along the upper side, limbs white with pink to violet throat behind upper lip, or purple throughout, palate densely papillose from throat to lower sinuses.\}...3. M. radicans

2. Horizontal runners not leafy, long, without nodes ("rhizomes"). Leaves forming close-packed rosettes with obscure internodes, with eglandular hairs, if present, short, 0.1-0.4(0.7) mm long. Calyx slender, campanulate, glabrous or with sparse, rarely dense eglandular hairs $0.2-0.3(0.4) \mathrm{mm}$ long; teeth $1-3 \mathrm{~mm}$ long. Capsule

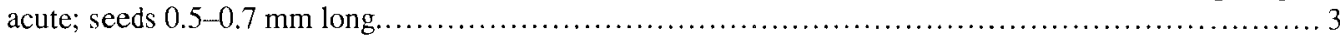

3. Corolla (6.5) 7.5-12 mm long along the upper side, the limbs pale blue, lilac or purple; palate densely papillose from throat almost to the sinuses of lower lip. Eglandular hairs, when present on leaves, on upper or both surfaces, rare and never only along margins; when present on calyx, on midribs of teeth ..... 1. M. pumilio

3. Corolla 5.2-7.5 (9) $\mathrm{mm}$ along the upper side, the limbs white; palate glabrous or sparsely papillose only in throat. Eglandular hairs, when present on leaves, confined to the margins; when present on calyx, confined to the margins of the teeth.... 2. M. novaezeelandiae

\section{Description}

Low perennial herb comprising dense leaf-rosettes on condensed erect stems connected by horizontal rhizomes. Leaves ?always opposite, the insertion obscured, ascending, obovate-spathulate, pale green and shiny above, grey-green and dull below (Wilson 422,681 ); petiole $3-30 \mathrm{~mm}$ long, with a membranous wing along either side; blade obovate to elliptic, $8-55 \times$ 2.5-18 $\mathrm{mm}$, longer than the petiole, gradually attenuate at base, serrate-dentate to shallowly undulate, sometimes almost entire, narrowly recurved, at apex acute to rounded, sometimes with a short acumen, glabrous or with short, scattered to moderately dense eglandular hairs $0.1-0.4(0.7) \mathrm{mm}$ long, usually confined to the upper surface, especially on the midrib and veins, sometimes also below, very rarely scattered along the margins. Inflorescences arising from the apex of leaf rosettes, ?always terminal, 1-4(-13)-flowered, $15-80(-140) \mathrm{mm}$ long; rhachis glabrous or shortly eglandular hairy, at least towards base; bracts absent from base of pedicels or ?caducous early; pedicels 5-40 mm long; bracteoles 1 on pedicel, rarely 2 (or ?subtending another bud), and alternate, narrow-linear to narrow-subulate $0.08-4 \mathrm{~mm}$ long, entire, glabrous, rarely puberulent. Calyx slender, campanulate, 2.5$5.5 \mathrm{~mm}$ long, 5-6 mm long in fruit, obscurely 5-angled, usually glabrous, sometimes with a few eglandular hairs $0.1-0.3(-0.4) \mathrm{mm}$ long on midrib of teeth; teeth triangular or narrowly so, c. 1-2.5 mm long, somewhat shorter than tube, rarely a little longer (Wehl AD 97014178), acute or short-acuminate. Corolla in bud with upper lip external to lower, when mature 7.5$12 \mathrm{~mm}$ long along upper side, glabrous apart from dense narrow-clavate hairs on the palate extending down to between the base of the abaxial filaments and scattered tiny glandular hairs outside, pale blue, lilac or purple, with tube at least sometimes (Hemsley 6481) white, the palate yellow or ?white (Black Millicent, AD 97625164 p.p.); tube slightly shorter than calyx to 1.5 times as long; upper lip 2.5-6.2 $\mathrm{mm}$ long, the lobes entire, bluntly acute, the sinus $0.6-1.6 \mathrm{~mm}$ deep; lower lip widely spreading from a narrow base, $5.5-10.9 \times 8.5-$ $14 \mathrm{~mm}$, the lobes rounded, finely erose-undulate, the sinuses $1.3-3.2 \mathrm{~mm}$ deep; palate comprising 2 blunt ridges extending from the throat to the sinuses of the lower lip. Stamens glabrous, both pairs inserted at the same level, halfway along corolla tube; filaments curved through $90^{\circ}$, adaxial filaments c. $1.2-1.7 \mathrm{~mm}$ long, abaxial c. $2.5-3.2 \mathrm{~mm}$ long; anthers $\mathrm{I} \times 0.4-0.55 \mathrm{~mm}$, with locules equal, widely divergent but not quite in line, confluent but distinct by incomplete cross-wall, antrorse, the connective on the posterior (adaxial) side, circular, sometimes dark, the filaments inserted laterally. Ovary ovoid, slightly compressed, glabrous; style 3.7-4.6 mm long, extended past all anthers; stigmatic lobes rhombic, $0.5-0.8 \times 0.4-0.7 \mathrm{~mm}$, equal 
or one of the lobes between half and equal the length of the other. Capsule (Copley 5182) included to slightly exserted from green enlarged calyx, ?indehiscent, ellipsoid, $5-7 \times 3-4 \mathrm{~mm}$, acute topped by a short obscure style remnant; seeds many, obliquely broadly ellipsoid, $0.5-0.65 \times 0.4-0.45 \mathrm{~mm}$, slightly angular, dark brown, finely densely reticulate with areolae \pm isodiametric.

\section{Typification}

Two collections of $M$. pumilio by Robert Brown match the protologue; one of more robust plants from Launceston (then Port Dalrymple), upon which the unnamed infraspecific taxon " $\alpha$ " was based, the other of very small plants from King Island, which formed the basis of taxon " $\beta$ ". Both contain much wellcollected material. With all other things being equal, the lectotype has been selected from among syntypes from the former collection for several reasons. Firstly, Brown placed it first, possibly as the most representative of his view of the species. Secondly, it contains more material overall. Finally, unlike taxon " $\beta$ ", it has developing fruits. Although not important in lectotypification, it does happen to be more representative of the species. From Brown's annotations, the duplicates seen of this collection were all available to him until after he completed his naming of the species and designated the infraspecific taxa. The BM syntype is fully annotated and is the choice as lectotype.

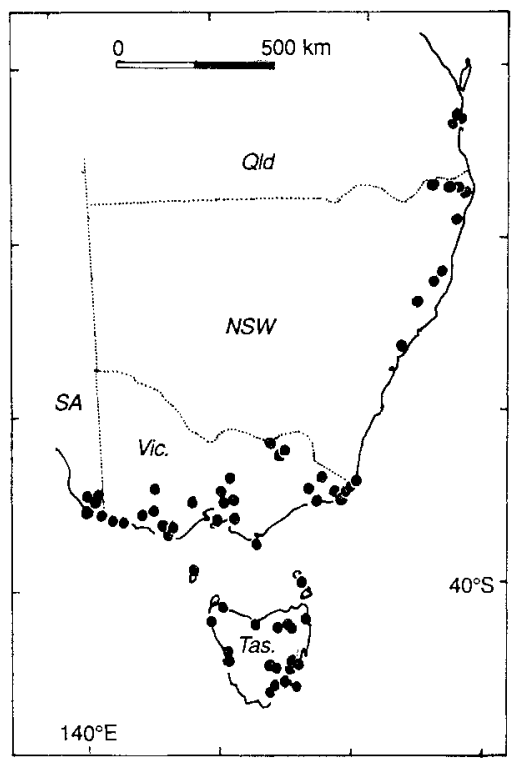

FIG. I-Distribution of Mazus pumilio R. Br. of southeastern Australia. (Lines of latitude and longitude are at $5^{\circ}$ intervals.)

\section{Distribution and Ecology}

M. pumilio is confined to eastern Australia from southeastern Queensland to Tasmania, and extending westwards as far as the southeastern corner of South Australia (fig. 1)

It grows in or on the margins of swamps or boggy sites. Flowering collections: (mid-September), midOctober-early February(-April).

\section{Conservation Status}

Most collections are old. It is likely that swamp drainage and clearing since European colonisation and associated grazing and spread of weeds have caused a substantial decline of the species. Although unlisted in Briggs \& Leigh's (1988) national and state listings of rare and threatened Australian plants, it may deserve a national status of at least 3R. Lang \& Kraehenbuehl (1987) recorded it as vulnerable in South Australia.

\section{Notes}

In material cultivated in the glasshouse (Chinnock 6505) the flaps of the stigma of a flower, touched 30 minutes after picking, gradually closed together over a period of 5 seconds.

\section{Selected and Cited Specimens Examined (129 seen)}

South Australia: South-Eastern (16 specimens seen) Anon. s.n. (AD 97625164 p.p - Herb. Black); R. Ba 2621 (AD); Mrs Dr Wehl s.n. (MEL 38792, AD 97014178); I.B. Wilson 422, 681 (AD).

Queensland: Darling Downs [?cultivated] (1) - S.R. Klose s.n. (BRI 028057); Moreton (4) - Anon. (Herb. J.H. Simmonds) 352 (BRI 114458).

New South Wales: North Coast (10) - J.S. Wilson s.n. (NSW 144600). Central Coast (1) - J.L. Boorman s.n. (NSW 144602). South Coast (3) --- T. \& J. Whaite 2843 (NSW).

Victoria: Northern Plains (3) - Rev. Wilson s.n. (MEL 93536). Western Highlands (3) - S. Johnstone s.n. (MEL 93533). Eastern Highlands (13) - B. Copley 5182 (AD). Western Volcanic Plains (4) - H.B. Williamson s.n. (MEL 38792). Western Coastal Plains (5) - A.C. Beauglehole 21574 \& E.W. Finck (MEL). Otway Ranges (1) - R.J. Chinnock 6505 (AD). Wilsons Promontory (1) — Meebold 2317 (M). Eastern Coastal Plains (11) - A.B. Wellington s.n. (MEL 524175).

Tasmania: King Island (8) - R. Brown 2648 (see type citation), I.D. Cameron s.n. (HO 27169). Furneaux (3) - J. Whinray s.n. (MEL 518053). North West (3) J. Somerville s.n. (HO 22241). North East (4) R. Brown s.n. (see type citation), T.E. Burns s.n. (HO 22233). West Coast (2) - G.S. Hope ANU 21567 (CANB). Midlands (1) - J. Somerville s.n. (HO 22237). 
Ben Lomond (2) - L.B. Moore s.n. (CHR 66835). East Coast (16) - M.J. Brown \& S.J. Harris s.n. (HO 31447), J.H. Hemsley 6481 (HO). South West (1) - J. Milligan 898 (HO, MEL, NSW). [Further details of specimens listed in this paper, e.g. collecting site and date, are available from the author, the Herbaria noted or from the Royal Society of Tasmania Library (Archives), GPO Box 1166M, Hobart, Tasmania, Australia 7001. Ed.]

\section{Mazus novaezeelandiae W.R. Barker, sp. n.}

Ourisia sp.: Hook., lc. Pl.6 (n.s. 2) (1843) t.545-546 (in note, t.567, as synonym of $M$. pumilio).

M. pumilio auctt. non. R. Br.: e.g. Hook., lc. Pl.6 (n.s. 2) (1843) t.567, p.p. (excl. Tasmanian reference); Hook. f., Fl. Nov.-Zel. (1853) 189, p.p. (excl. Australian records); Hook. f., Fl. Tasm. 1 (1857) 290, p.p. (as to NZ reference); Benth., Fl. Aust. 4 (1868) 484, p.p. (as to NZ reference); Cheeseman, Man. NZ Fl. (1906) 485 , p.p. (excl. Australian and Tasmanian reference); Allan, Fl. NZ 1 (1961) 848, p.p. (excl. Australian and Tasmanian reference); W.R. Barker, Evol. Fl. Fauna Arid Aust. (1982) 342, p.p. (as to NZ occurrence); Johnson \& Brooke, Wetland Pl. NZ (1989) 284, fig. 506.

Species nova $M$. pumilioni habitu perenni, inflorescentia in rosula principali terminali, stolonibusque sterilibus affinis, sed differt corolla breviore, alba fauce glabra vel sparsius pubescenti, foliis obtusioribus pilisque eglandulosis ubi praesentibus, ad margines foliorum dentiumque calycis limitatis; $M$. radicanti, specie Novae Zeelandiae altera, differt foliis in rosulis, pilis eglandulosis, ubi praesentibus, brevibus, calyce angusto, campanulato, indumento, ubi praesenti, non nisi marginali, dentisque brevioribus, corolla semper alba vel ita paene omnino, fauce glabra vel sparsius pubescenti, et seminis parvis.

\section{Holotypus}

B.V. Sneddon \& T. Moss s.n., 8.xii.1986, Hawkins Gully Stream about $0.5 \mathrm{~km}$ from its outlet into the Makara Stream estuary, Wellington, map and grid reference: NZMS 260/R27: 541967, 41 ${ }^{\circ} 13^{\prime} 39^{\prime \prime S}$, $173^{\circ} 43^{\prime} 24^{\prime \prime E}$; grazed turf between scattered Juncus clumps on seasonally wet stream terrace; largest plants were from the shaded periphery of Juncus clump bases; corolla colour: lobes white, slight purple tinge to margins, throat white, [sides of mouth at base of lateral lobes] with broken yellow lines on raised mounds; entomophilous hanky-panky ... none, AD 99001047. lsotypi: AK, CHR, WELT, WELTU, OTA, K, A, NY, BM, L, NSW, BRI, HO, CANB, MEL, PERTH, E, P, $\mathrm{G}, \mathrm{W}$.

\section{Description}

Low perennial herb consisting of dense leaf rosettes with condensed erect stems, connected by horizontal runners (non-leaf-bearing rhizomes). Leaves dense, obscuring insertion, but opposite, obovate to spathulate or narrowly so, possibly discolorous (no annotations on specimens); petiole $3-50 \mathrm{~mm}$ long, lined on either side by membranous wing decurrent from blade; blade obovate to obovate-elliptic or narrowly so, $650 \times 3$ $19 \mathrm{~mm}$, longer than to equal to, rarely shorter than petiole, gradually attenuate at base, entire to undulateserrate, narrowly recurved, obtuse to rounded at apex, rarely with very short acumen, glabrous or ciliate by moderately dense, rarely occasional, eglandular hairs $0.1-0.4(0.5) \mathrm{mm}$ long on margin only. Inflorescences terminal, arising from apex of leaf rosettes, (1-)3-5(7)-flowered, (15) 20-110 (125) mm long; hachis glabrous; bracts absent; bracteoles one per flower, linearsubulate, 0.6 -2 (3.5) $\mathrm{mm}$ long, glabrous; pedicels 3-15 (21) mm long. Calyx slender, campanulate, 3.35.2 (-6: Williams WELT 59894) $\mathrm{mm}$ long, somewhat longer in fruit, 10-angled or -ribbed, usually glabrous, rarely with one or two eglandular hairs $0.1-0.3(0.5) \mathrm{mm}$ long, lining margins of teeth; teeth triangular or narrowly so, 1.4-3.0 mm long, shorter to longer than tube, short to long acuminate, rarely bluntly acute. Corolla in bud with upper lip external to lower, when mature 5.2-7 (9: Williams WELT 59894) mm long along upper side, white (Barker 5758, Wright 2521, Ogle WELT 68843), glabrous apart from palate; tube shorter or longer than calyx; upper lip c. 3-3.5 (4.3: Williams WELT 59894) mm long, lobes entire, acute, sinus c. 0.5-0.7 (?0.8: Williams WELT 59894) $\mathrm{mm}$ long; lower lip widely spreading from narrow base c. $4.5-6.8 \times 6-10$ (?12: Williams) $\mathrm{mm}$, lobes rounded, sinuses c. 0.9 $2.5 \mathrm{~mm}$ deep; palate 2 elevations extending from throat to sinuses of lower lip, glabrous or with scattered linearclavate papillae $0.1-0.45 \mathrm{~mm}$ long in throat and extending only up to halfway to sinuses, with 1-2 pale to mid-yellow blotches on each elevation (Barker 5758). Stamens glabrous, inserted at same level, halfway along corolla tube; filaments curved through $90^{\circ}$, adaxial filaments c. $0.9-1.5 \mathrm{~mm}$ long, locules widely divergent, not quite in line, confluent, but distinct by incomplete cross-wall, antrorse, connective on adaxial side, the filaments inserted laterally. Ovary compressed-ovoid, glabrous; style c. 3-3.5 mm long (probably longer in Williams WELT), extended past stamens; stigmatic lobes rhombic 0.6-1.2 × 0.5-1.0 mm. Capsule (Thompson CHR 360091) included in green enlarged calyx, ellipsoid, obtuse with short style remnant, c. $4.5 \times$ 2.5-3 mm; seeds many, c. $0.7 \times 0.45 \mathrm{~mm}$, dark brown, finely densely reticulate, the areolae \pm isodiametric. Chromosome number: $\mathrm{n}=19$ (Hair \& Beuzenberg 1960: voucher Druce CHR 100151). 


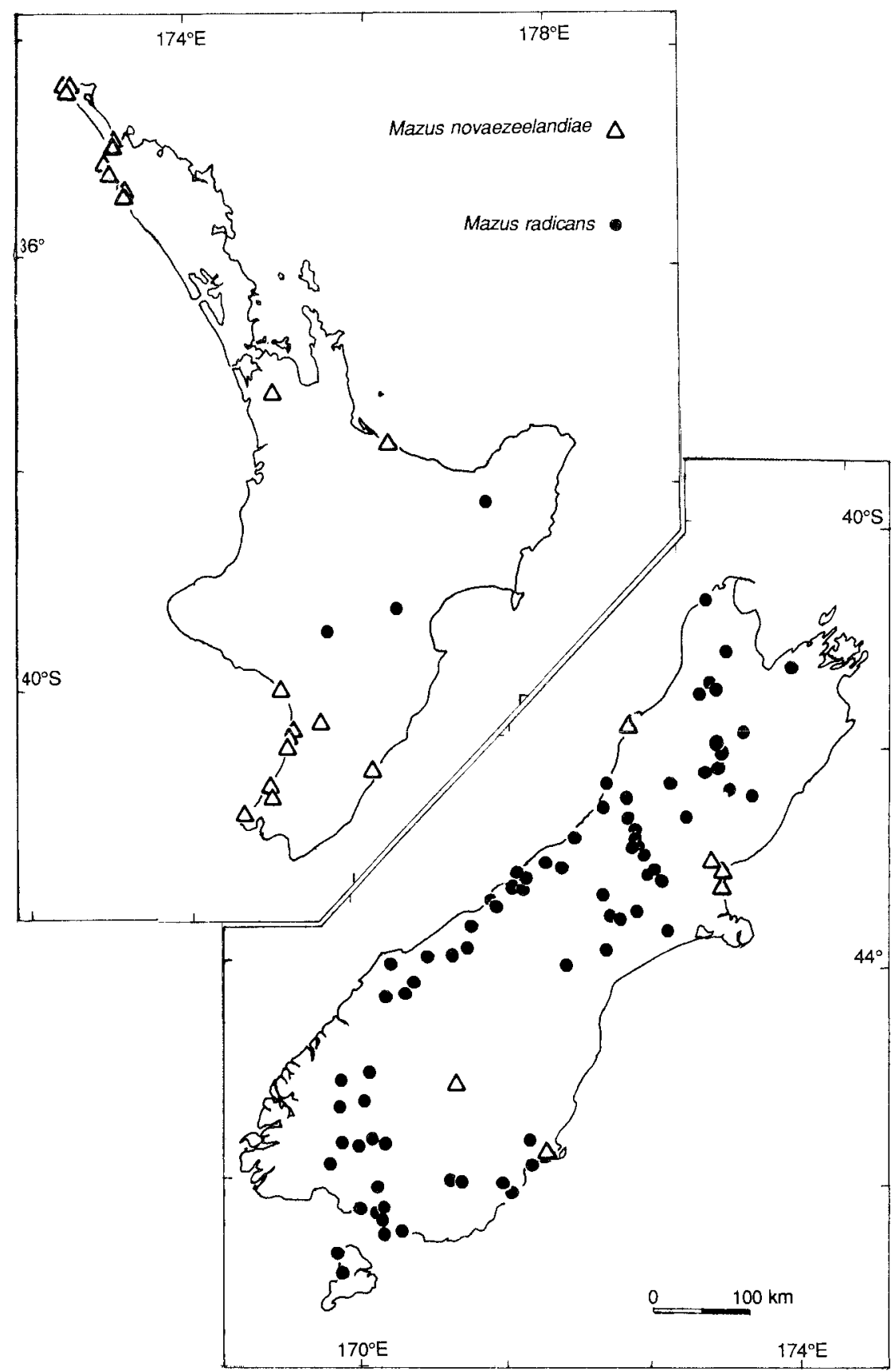

FIG. 2 - Distribution of Mazus novaezeelandicae W.R. Barker and M. radicans (Hook.f.) Cheeseman of New Zealand. (Lines of latitude and longitude are at $2^{\circ}$ intervals.) 
Distribution and Ecology

Restricted to New Zealand, $M$. novaezeelandiae occurs on both North and South Island, but not on Stewart Island (fig. 2).

The species occurs from sea level to low altitudes in a variety of situations, often damp or swampy sites, including grassy plains, coastal turf, associated with dunes, or under forest on tracksides or banks. Sometimes the habitat is subject to grazing. The species flowers from November to February, rarely March.

\section{Conservation Status}

Collections from the last 25 years are few, particularly on the South Island, and the species is considered vulnerable (Johnson \& Brooke 1989).

\section{Notes}

$M$. novaezeelandiae was previously confused with both $M$. pumilio of Australia and $M$. radicans of New Zealand which in the past (e.g. by Cheeseman 1906, and Allan 1961) were distinguished on flower size, so that small-flowered forms of $M$. radicans were placed in this species. Salmon (1963) recognised the differences between the two species in indumentum but, according to him, $M$. radicans only had large flowers.

Details of corolla coloration are all too few. Nevertheless, in my experience and from those few specimens with notes, the corolla is white. The occasional blue coloration referred to by Allan (1961) probably applies to the small-flowered form of $M$. radicans.

\section{Relationships}

$M$. novaezeelandiae is closely allied to the Australian species $M$. pumilio with which, till now, it has been confused. It is likely that they are sister species, with the floral differences reflecting the general differences between the floras on either side of the Tasman, many New Zealand species tending to be less showy in coloration and of smaller flower size and more highly autogamous than their Australian congeners (Barker 1982b, Lloyd 1985).

Whether $M$. radicans is closely allied awaits a revision and anatomical investigation of the horizontal runners in each species.

\section{Orthography}

Since formulating the spelling "novaezeelandiae" and retuming loan specimens so annotated, a note by Garnock-Jones (1987) has appeared suggesting use of "novae-zelandiae" in new epithets. Unfortunately, he gave no basis for his choice, other than implying it conformed with accepted usage of Latin and Latinisation. I retain my original spelling as, although Stearn (1966) gives the form "novae-zelandiae" for "of
New Zealand", he gives "Zeelandia" as the appropriate Latinisation of Zeeland (the Netherlands) from which New Zealand derives. Use of the form "novaezeelandiae" has occurred previously in literature (e.g. Euphrasia Sect. Novae-zeelandiae Du Rietz; Hydrocotyle novae-zeelandiae DC.), and there is no rule against this spelling. The ICBN (Art. 23.1, Art. 73.9) allows original spellings in which the hyphen has been omitted. This has been deliberately done here.

Selected and Cited Specimens Examined ( 68 seen) NEW ZEALAND: North Island: North Auckland (15 specimens seen) - A.E. Wright 2521 (AK 143684). South Auckland (14) - A.P. Druce s.n., voucher specimen, $\mathrm{n}=19$ (CHR 100151). Wellington (19) W.R. Barker 5758; B.V. Sneddon \& E. Vitek ([NZMS 260 R27 540967]; AD [dupl. to be distributed; topotype]); C.C. Ogle s.n. (WELT 68843); B.V. Sneddon \& T. Moss s.n. (see type citation).

South Island: Nelson (1) - D. Kelly \& G.C. Kelly s.n. (CHR 250117). Canterbury (7) - J. Thompson s.n. (CHR 360090, 360091). Otago (3) - B. Campbell s.n. (CHR 188742).

\section{Mazus radicans (Hook. f.) Cheeseman}

$M$. radicans (Hook. f.) Cheeseman, Man. NZ Fl. (1906) 486; aucct. e.g., Cheeseman, Man. NZ Fl. (2nd edn) (1925) 772; Allan, Fl. NZ 1 (1961) 848; Johnson \& Brooke, Wetland PI. NZ (1989) 283, 284, fig. 38. Mimulus ?radicans Hook. f., Fl. NZ (1853) 188; Hook. f., Fl. Tasm. 1 (1857) 290 (in footnote; "Better specimens ... prove this plant to be Mazus" but combination not made).

Type citation: "Northem Island. Tararua Mountains and Wairarapa Valley, Colenso." Lectotype here designated: Colenso 145 or 1963, s. dat. N. Zd., K p.p. (Hern. Hook.: specimen to the left of the 1963 label). Other syntypes partly isolectotypes: remaining material on Colenso 145 \& 1963 K. p.p. Possible isosyntype, even isolectotype: Anon. s.n., s. dat., Head of Wairarapa Valley, WELT 23519 (Herb. Colenso).

Ourisia montana Buchanan, Trans. NZ Inst. 19 (1887) 214, t.14; [?Ashwin in] Allan, Fl. NZ 1 (1961) 1033, pro syn. of Mazus radicans.

Type citation: "Mount Alta Range, at 5,000 to 6,000 feet altitude." Holotype: Anon. (Herb. Buchanan) 2, s. dat., Without locality, "Ourisia montana Buch., ms", WELT p.p., AD (col. slides).

\section{Description}

Perennial herb; main branches prostrate, rooting at nodes, leaf-bearing or subterranean and horizontal; 
lateral branches short, leafy, with distinct internodes. Leaves spathulate, ?discolorous, at least sometimes brown blotched towards margins; petiole 3-70 $\mathrm{mm}$ long, lined on either side by membranous wing; blade obovate to elliptic or broadly so, $5-35 \times 4-15 \mathrm{~mm}$, shorter or longer than petiole, gradually or abruptly attenuate at base, margin shallowly undulate to serratecrenate, slightly recurved, broad-acute to rounded at apex, with soft, moderately long to long eglandular hairs above and along margins. Inflorescences terminal on the short lateral branches, 1-3(4)-flowered, 15-130 mm long; rhachis glabrous or eglandular hairy, at least in distal parts; bracts rarely present subtending pedicels, ?caducous early; bracteoles similar in size and shape, 1-?2 alternate along pedicels, the second (lower) bracteole possibly a bract with bud still to develop, narrow-linear to narrow-subulate, $2.5-7 \mathrm{~mm}$ long, entire, glabrous or eglandular hairy; pedicels 3 $35 \mathrm{~mm}$ long. Calyx broadly campanulate, $3-7.5 \mathrm{~mm}$ long, elongating to $8-22 \mathrm{~mm}$ in fruit, \pm smooth or obscurely 5 -angled at least on teeth, with moderately dense to dense, rarely (Bunell 131) sparse, weak eglandular hairs $(0.3) 0.5-0.8 \mathrm{~mm}$ long; teeth triangular or narrowly so, $2.5-4 \mathrm{~mm}$ long, as long as tube or a little shorter or longer, rarely much longer (e.g. Herb. Colenso WELT 23519). Corolla in bud with upper lip external to lower, when mature $5.5-17 \mathrm{~mm}$ long along upper side (to apex of upper lip), coloration (from Barker 5798, with additions from Allan 1961, Salmon 1963 photo, Melville 5619) externally white with purple flesh, intemally with upper lip mid to deep purple or violet, with lower lip white with white to yellow palate, glabrous apart from the palate and scattered short glandular hairs outside; tube as long as calyx to almost twice length, glabrous; upper lip 4-8.5 $\mathrm{mm}$ long, lobes entire, bluntly acute, sinus c. 1-3 mm deep; lower lip widely spreading from nartow base, $5-22 \times 5.8-16 \mathrm{~mm}$, lobes rounded, finely undulate, sinuses c. $3 \mathrm{~mm}$ deep; palate 2 yellow longitudinal elevations extending from throat to base of lower lobes covered by dense narrowclavate hairs. Stamens glabrous, inserted at same level, halfway along corolla tube above the ovary; adaxial filaments curved through $90^{\circ}$, c. 1-2.5 mm long, abaxial filaments not as markedly curved c. 2--3.5 mm long; anthers $1-1.3 \times 0.3-0.5 \mathrm{~mm}$ (when wet), with locules equal, widely divergent so that almost in line, confluent but quite distinct by incomplete cross-wall between, dehiscing antrorsely (towards anterior), connective on posterior side dark, the filaments inserted laterally. Ovary glabrous, ovoid, c. 1.1-1.7 mm long, ?compressed; style c. 3-7 mm long, extended well past both pairs of anthers; stigmatic lobes rhombic $0.5-1 \times 0.4-0.8 \mathrm{~mm}$. Capsule persisting undehisced and included in pink to red, greatly enlarged calyx, broadly ellipsoid, 6.5$7.5 \times 3.5-5.5 \mathrm{~mm}$, compressed, truncate, topped by style base, the capsule ellipsoid-acuminate when few seeds formed (Chapman CHR 219792); seeds usually many, rarely few forming from many ovules, perfectly broadly ellipsoid ( 0.8 ?immature) $1-1.2 \times 0.7-0.8 \mathrm{~mm}$, yellow-brown (?immature) to darkish brown, finely densely reticulate with aureolae isodiametric. Chromosome number: $\mathrm{n}=52$ (Hair \& Beuzenberg 1960: voucher Brockie CHR 101965).

\section{Typification}

Mimulus ? radicans Hook. f. ( $\equiv$ Mazus radicans (Hook. f.) Cheeseman). There is no means of knowing what plants go with which label. From the locality cited in the protologue they came presumably from different localities (neighbouring?). Allan (1961) has cited the "Type" as 1963, and, under the present code, this could constitute a lectotypification even if there were not his intention. However, it is impossible to know how much and to which specimens the label annotated with 1963 applies. I have, therefore, chosen a single specimen as lectotype, to the left of this label, and with two flowers and a bud. Some of the other syntype material may be isolectotype.

An unnumbered collection "Anon. WELT 23519" from the Colenso Herbarium bears a label in Cheeseman's hand ("Mazus radicans, Cheesm = Mimulus radicans, Hk. f."). There is no original label. This collection matches the $\mathrm{K}$ material well and comes from the type localities and therefore may be a duplicate of one of the two syntype collections.

Ourisia montana Buchan. Mr J. Fox of WELT (pers. comm.) has provided the following information on the holotype, located in a folio of Buchanan specimens:

"The Buchanan material ... consists of 2 specimens mounted on a sheet with specimens labelled Ourisia caespitosa Hook. f., Ourisia glandulosa Hook. f. \& Ourisia uniflora Buchanan ms. This last sp. is probably Euphrasia revoluta Hook. f. Ourisia uniflora was apparently not published, but Buchanan distinguishes his Ourisia montana from Ourisia uniflora in [the protologue of] Ourisia montana. The left hand specimen of Ourisia montana matches the illustration (t. 14) accompanying the protologue.

Using the key to Australasian Mazus in this paper, he found that "both specimens clearly key out to Mazus radicans". I have seen colour slides of the material and concur with his statement.

\section{Distribution and Ecology}

Endemic to New Zealand on North, South and Stewart Islands (fig. 2), $M$. radicans occurs usually from 100 $1100 \mathrm{~m}$ a.s.l., but down to sea level on the Southland coast and on Stewart Island. 
The species occupies damp, sometimes periodically inundated gro und, often forming dense mats; on coastal sites, in turf or damp sand or sandy peat in clearings in coastal bush or associated with dunes; elsewhere, at the edge of or within forests, on river banks, flats or terraces, or in grassy areas or tussock grassland. There are conflicting reports as to whether it will survive topdressing (Adams CHR 205852, Anderson CHR 319095). The species flowers usually in December and January, with rarer records in November and February, and one in April (Healy CHR 79218).

\section{Notes}

A variable plant. From ecological annotations $M$. radicans in open grassland sites apparently has small short-petiolate leaves with short inflorescences, while in forested or more sheltered sites it has long petioles and inflorescences.

Much smaller flowers 6-7 mm long along upper side with almost as short lower lips occasionally occur in material of this species. These are, no doubt, the southern form of $M$. radicans referred to by Johnson \& Brooke (1989). In most material (e.g. Kirk WELT 59901, Petrie AK 7624, Colenso WELT 23519, Kirk WELT 59899, Kirk WELT 59898), they occur amongst specimens also with larger flowers, while in Leask WELT 64146, Kirk WELT 59902 and Aston WELT 59926, no large flowers are present and the very short styles (c. $2.5-3 \mathrm{~mm}$ long) on the capsules make it unlikely that large flowers were ever present on the material collected.

It is unlikely that this small-flowered material represents an intergrade with $M$. novaezeelandiae; the species is unknown from these locations. Apart from differences in dimensions of the calyx, corolla parts and style, the plants have all the characteristics of $M$. radicans. Thus, the calyces are stout and densely covered by long eglandular hairs, and the palate is densely covered with clavate hairs. Since these small flowers tend to occur on material with small leaves and reduced rhachis and pedicel lengths, it is possible that this is a response to environmental conditions, of a sort probably not conducive to vigorous growth. Furthermore, the typical larger flower form is showy and probably outcrossed. It follows that the small obscure flowers may be self-pollinating, possibly "budautogamous", which can be produced on the same plant as larger chasmogamous flowers, as commonly occurs in plants with cleistogamous flowers. Perhaps this occurs when environmental conditions are unfavourable to visits by insect pollinators. The flowers, therefore may be analogous to reduced flowers terminating inflorescences in various Scrophulariaceae (e.g. Euphrasia: Barker 1982b). Unfortunately material is inadequate to investigate the developmental aspects of this hypothesis. Field and growth observations are obviously needed.
Bunell 131 is unusual in only a scatter of eglandular hairs on the calyx. In all other respecis it is typical of $M$. radicans.

Selected and Cited Specimens Examined (136 Seen) NEW ZEALAND: North Island: South Auckland (2 specimens seen): - K.W. Allison s.n. (CHR 328101A, CHR 328101B - Herb. Carse 1213/). Taranaki (3): A.P. Druce s.n. (CHR 158691). Gisborne - see under "Cultivated" below. Hawkes Bay (4) - A. P. Druce s.n. (CHR 209695). Wellington (2) - Anon. s.n. (see type citation); Colenso 145 or 1963 (see type citation).

South Island: Nelson (11) - W.R. Barker 5798; B. Malcolm \& E. Vitek (dupl. to be distributed). Marlborough (1) - J.H. MacMahon s.n. (AK 7621 Herb. Cheeseman). Canterbury (32) - J.A. Anderson s.n. (CHR 319095); E.M. Chapman s.n. (CHR 219792); A. Latter s.n. (CHR 146045); R. Melville 5619 (CHR 133144); L.R. Stemmer s.n. (CHR 279745). Westland (36) - R.A. Adams s.n. (CHR 205852); P. Wardle s.n. (CHR 356152); Otago (9) - [F.P. Bunel1] 131 (OTA); D. Petrie s.n. (AK 7624-Herb. Cheeseman). Southland (23) - B.C. Aston 708 (WELT 59926); A.J. Healy s.n. (CHR 79218); P.N. Johnson s.n. (CHR 253257); T. Kirk s.n. (WELT 59899).

Stewart Island (3) - D. Leask 56 (WELT 64146); H.D. Wilson \& G. Loh 99 (CHR 322495).

Cultivated (8) - W.B. Brockie s.n., voucher specimen $\mathrm{n}=52$ (CHR 101965); Pittynes s.n. (source Gisbome province) (AK 27485).

\section{POSSIBLE HYBRIDISATION BETWEEN M. RADICANS AND M. NOVAEZEELANDIAE}

A collection, Anon. WELT 59927, from the coast just north of Wellington, contains a mixture of specimens, some typical of $M$. novaezeelandiae with their small glabrous narrow-campanulate calyces and small corollas with a subglabrous palate, others resembling the putatively "bud autogamous" form of $M$. radicans, with small campanulate calyces covered by moderately dense long eglandular hairs and small corollas with the palate densely covered by clavate hairs, and still others resembling small-flowered $M$. radicans in all characters but for the subglabrous calyces.

Two explanations seem most likely. The first is that these variants have resulted from hybridisation. If a clinical intergradation were the cause, this phenomenon would be expected to occur more widely throughout both islands. Instead, the two species otherwise show little other evidence which could be attributed to intergradation (see $M$. radicans, "Notes"); and have largely divergent, if overlapping ranges, $M$. radicans apparently occurring at higher altitudes 
or latitudes, both indicating possibly divergent climatic preferences.

The other likely explanation is that the intermediate specimens are a variant with a glabrous calyx of the small-flowered form of $M$. radicans, paralleling the case cited in "Votes" under $M$. radicans for the largeflowered form.

Only study of both species in cultivation together with crossing programme and possibly the discovery of similar situations in the field will shed light on the situation.

\section{Specimens Examined}

NEW ZEALAND: North Island: Wellington-Anon. (Herb. B.C. Aston) s.n. (WELT 59927).

\section{ACKNOWLEDGEMENTS}

Assistance by Dr Barry Sneddon, Dr Bill and Nancy Malcolm and Dr Murray and Tatjana Parsons in directing me to living New Zealand Mazus is gratefully acknowledged. The Department of Plant and Microbial Sciences, University of Canterbury and Botany Division, DSIR, funded much of my fieldwork in New Zealand in early 1989. Dr Sneddon and Mr Tom Moss are thanked for making an excellent type collection of $M$. novaezeelandiae. Dr Bob Chinnock provided propagation material, which was maintained at the Botanic Gardens of Adelaide by Mr Trevor Christensen. Mrs Robyn Barker helped with the determination of latitudes and longitudes. Miss Tina Eadsforth is thanked for typing the manuscript. I am gratefuI to Dr Phil Garnock-Jones for his comments as referee, and to Dr Patrick Brownsey for expediting the information on the type of Ourisia montana.

\section{REFERENCES}

ALLAN, H.H., 1961: Mazus Lour., 1790. FLORA OF NEW ZEALAND, VOL.1. Government Printer, Wellington: $848-849$.

BARKER, W.R., 1982a: Evolution, adaptation and biogeography in arid Australian Scrophulariaceae. In Barker, W.R. \& Greenslade, P.J.M. (Eds): EVOLUTION OF THE FLORA AND FAUNA OF ARID AUSTRALIA. Peacock Publications, Frewville (now Norwood), South Australia: 341-350.

BARKER, W.R., 1982b: Taxonomic studies in Euphrasia L. (Scrophulariaceae). A revised infrageneric classification, and a revision of the genus in Australia. J. Adelaide Bot. Gard. 5: 1-304.

BLACK, J.M., 1926: Scrophulariaceae. FLORA OF SOUTH AUSTRALIA. Government Printer, Adelaide: 504 514.

Bonatl, G., 1908: Contribution à l'Etude du genre Mazus Lour. Bull. Herb. Boissier, Ser. 2, 8: 525-539.
Briggs, J.D. \& LEIGH, J.H., 1988: RARE OR THREATENED AUSTRALIAN PLANTS. Aust. Natl Pks Wildl. Serv. Spec. Publ. 14.

BURBIDGE, N.T., 1955: ANINDEX TO THE MICROFILM OF ROBERT BROWN'S BOTANICAL DESCRIPTIONS (MANUSCRIPT) OF AUSTRALIAN PLANTS HELD BY THE BRITISH MUSEUM (NATURAL HISTORY). CSIRO, Division of Plant Industry, Canberra.

CheEseman, T.F., 1906: MANUAL OF THE NEW ZEALAND FLORA. Government Printer, Wellington.

GARNOCK-JONES, P., 1987: Orthographic changes for names of New Zealand vascular plants. In Connor, H.E. \& Edgar, R. (Eds): Name changes in the indigenous New Zealand flora, 1960-1986 and Nomina Nova IV, 1983-1988. NZ J. Bot. 25: 118-120.

Hair, J.B. \& Beuzenberg, E.J., 1960: Contributions to a chromosome atlas of the New Zealand flora. IV. Miscellaneous families. NZ J. Sci. 3: 432-440.

HOOKER, J.D., 1853: Scrophularineae. In THE BOTANY.THE ANTARCTIC VOYAGE OF H.M. SHIPS EREBUS AND TERROR IN THE YEARS $1839-1843 \ldots$ II. FLORA NOVAE-ZELANDIAE. Lovell Reeve, London: 187-200.

HOOKER, J.D., 1857: Scrophularineae. In THE BOTANY. THE ANTARCTIC VOYAGE OF H.M. SHIPS EREBUS AND TERROR IN THE YEARS 1839-1843 ... III. FLORA TASMANIAE. I. DICOTYLEDONAE. Lovell Reeve, London: 289-298.

JOHNSON, P.A. \& BROOKE, P.A., 1989: WETLAND PLANTS IN NEW ZEALAND. DSIR Publishing, Wellington.

Lang, P.J. \& Kraehenbuehl, D.N., 1987: PLANTS OF PARTICULAR CONSERVATION SIGNIFICANCE IN SOUTH AUSTRALIA'S AGRICULTURAL REGIONS: INTERIM REPORT. Native Vegetation Management Branch, Conservation Programmes Division, South Australian Department of Environment and Planning, Adelaide.

Lı, H.-L., 1954: The genus Mazus (Scrophulariaceae). Brittonia 8: 29-38.

Li, H.-L., 1978: Scrophulariaceae. In Li, H.L. et al. (Ed. comm.): FLORA OF TAIWAN. Vol. 4: 551-616.

LLOYD, D.G., 1985: Progress in understanding the natural history of New Zealand plants. NZ J. Bot. 23: 707722.

LOURIERo, J. DE, 1790: Mazus. FLORA COCHINCHINENSIS. Vol. 2: 385 .

Robertson, E.L., 1957: Scrophulariaceae. In Black, J.M.: FLORA OF SOUTH AUSTRALIA. 2nd edn: 761773.

ROYEN, P. vAN, 1983: Scrophulariaceae. ALPINE FLORA OF NEW GUINEA: 2857-2924.

SALMON, J.T., 1963: NEW ZEALAND FLOWERS AND PLANTS IN COLOUR. Reed, Wellington.

SaLMON, J.T., 1967: A FIELD GUIDE TO THE ALPINE PLANTS OF NEW ZEALAND. Reed, Wellington.

STEARN, W.T., 1966: BOTANICAL LATIN. Nelson, London.

SteEnis, C.G.G.J. VAN, 1958: Miscellaneous notes on New Guinea plants V.15. The genus Mazus (Scrophulariaceae). Nova Guinea, n.s. 9: 31 . 